International Journal of Instruction e-ISSN: 1308-1470 • www.e-iji.net

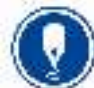

April 2021 • Vol.14, No.2

p-ISSN: 1694-609X

pp. 289-304

Article submission code

20191125152324
Received: 25/11/2019

Revision: 13/09/2020
Accepted: 05/10/2020

OnlineFirst: 21/01/2021

\title{
The Effect of the Scientific Approach-Based Learning on Problem Solving Skills in Early Childhood: Preliminary Study
}

\section{Een Yayah Haenilah}

Early Childhood Education Departement, Universitas Lampung, Indonesia, een.yayahhaenilah@fkip.unila.ac.id

\section{Hermi Yanzi}

Civic Education Departement, Universitas Lampung, Indonesia, hermi.yanzi@fkip.unila.ac.id

Rizky Drupadi

Early Childhood Education Departement, Universitas Lampung, Indonesia, rizky.drupadi@fkip.unila.ac.id

The problem of this study was the lack of problem-solving skills in early childhood, mostly in developing countries including Indonesia. This study examines the effect of the scientific approach-based learning process on problemsolving skills of early childhood and analyse the effectiveness of scientific approach-based learning to improve problem solving skills in early childhood. This study was conducted at Al-Kautsar Kindergarten in Bandar Lampung, Indonesia. The research method was a quasi-experiment. This research used one grup pre-test and post- test design. The data was collected using observation, documentation guidilines, and performance assesment. The instrument used in this research was the observation sheet in the form of an assessment rubric type rating scale. The data analysis was done by using descriptive analysis and simple linear regression. The results show that there were a significant difference in scores between before and after the treatment using the scientific approach-based learning process and a significant effect of this approach on problem solving skills of early childhood.

Keywords: scientific approach, learning, problem solving skills, early childhood, skills

\section{INTRODUCTION}

Indonesia is famous for its democratic society, where the community must be accustomed to diversity respect, differences for social justice for the community without the exception of children respect. Children have to learn the basic democratic life skills. Too many children still do not enjoy their full rights due to discrimination, bullying, physical, psychological, sexual, and verbal abuses on children, whereas children are also part of social beings.

Citation: Haenilah, E. Y., Yanzi, H., \& Drupadi, R. (2021). The Effect of the Scientific ApproachBased Learning on Problem Solving Skills in Early Childhood: Preliminary Study. International Journal of Instruction, 14(2), 289-304. https://doi.org/10.29333/iji.2021.14217a 
Children are not miniature of adults. Children are unique individuals whose existence must be recognized. Children are part of the family, a group of relatives, opposing environments, society, the country, and the world. To be a member of the environment from the outset, the child needs to learn the rules of living in a community from the outset. Early on, children must be trained with democratic life skills to become part of global society. Democratic life of social-emotional capacities is that children need to be productive citizens and healthy individuals in a modern, diverse society.

(Gartrell, 2012) identified five democratic life skills as follows: (1) finding acceptance as a member of the group and as a worthy individual, (2) expressing strong emotions in non-hurting ways, (3) Solving problems creatively-independently and in cooperation with others, (4) accepting unique human qualities in others, and (5) thinking intelligently and ethically. All these life skills may result in creating good citizens who are able to solve problems well for global community (Gartrell, 2012).

Izzaty (2010) adds in her research that there are three reasons about the importance of problem solving skill for early childhood, those reason are: (1) influencing the function of self-adjustment innfacing the conflict; (2) Doing positive and continual repetition to form those competences; and (3) positive problem solving which possibly influence the relationship with friends. The problems faced by children should be immediately solved or responded. In many cases, adults often getting involved and solve the problem that actually should be solved by their children. However, whatever problems faced by children even only small thing can be an opportunity for children to develop their problem solving skill (Brown, 1988).

In facing global competition in this century, educational orientation has led to $21 \mathrm{st}$ century thinking skills which include critical thinking, problem solving, communication, collaboration, information, media and technology (Urbani, Roshandel, \& Michaels, 2017) For this reason, learning models are needed to encourage children to be active, innovative, creative, and pleasantly.

In particular, actually critical thinking is an essential characteristics of children because naturally they are in a period of critical thinking, have a high curiosity, and are never satisfied with single answer. The most potential period for learning, children as unique persons like to imagine, have a short concentration range, become part of social beings, and always want to try new things (Aisyah, Amini, Chandrawati, \&Novita, 2014). It is true, that a child is a person who always thinks critically, and like a scientist at her/his age, always does activities to prove many things. This situation illustrates that, in fact, human being in their early childhood are able to conduct their own experiments and research and solve the problems they face. For this to happen effectively, a teacher has an important role to guide children by providing appropriate materials, and most importantly, to help them understand the materials, and to encourage them to find and develop their own understanding of the materials (Piaget, 1973; Haenilah, 2015).

The next important thing is to answer questions about: When and how can children think scientifically to solve problems? The answer to this question is teachers' responsibility to facilitate the children to be able to do so. The reason is that, in fact, the characteristics 
of early childhood will only appear if the children learn in pleasant conditions, then play becomes the only vehicle to stimulate thinking skills in early childhood. Emphasizing the importance of learning through plays activates sensorymotoric early childhood (Pellegrini \& Smith, 1998; Martuti, 2008) .This effort is carried out through the child's physical relationship with their environment. Sensory motoric needs of children are supported when they have the opportunity to build social relationships, related to a variety of materials and game equipment both inside and outside the room. Example playing sociodrama reduces children's aggression behaviour(Hart \& Tannock, 2013). This condition is experienced by children when they are given the opportunity to move freely, play in the yard or on the floor or on tables and chairs, and connect with people. Sensory motoric needs of children are supported if the environment provides the child's chance to use a variety of game tools with many colours, textures, sizes, and various types of different play materials to support each child's development needs. It should be well organized, comfortable, and personable and offer a variety of manipulations for cognitive, social, emotional, and physical development (Turk et al., 2015).

Knowledge is re-created and built from within the child through observation, experience, and understanding. Vygotsky in says that "Knowledge is not obtained by being transferred from others, but rather is something that is built and created by children. Vygotsky believes that learning is a process that cannot be forced from the outside because children are active learners and have a psychological structure that controls their learning behavior".

The constructivist experts assume that the only tool available for someone to know something is his senses. A person interacts with objects and their environment by seeing, hearing, smelling, touching, and feeling it. This shows that knowledge refers more to one's experience of the world than to the world itself (Trianto, 2014). Cognitive learning theory emphasizes mental processes such as thinking, memory, and problem solving that depend on how far the child actively manipulates and interacts actively with the surrounding environment.

(Piaget, 2013) states that: ... Children do not learn to experiment simply by watching the teacher performing experiments ', he warns' or by doing exercises organized in advance; they learn by a process of trial and error, working actively and independently, that is, without restriction and with sample time at their disposal.

Efforts to teach children through a play-based scientific approach have consequences for the management of children's learning environments. Some important things that must be considered by education are to (1) provide opportunities to play indoors and outdoors, (2) provide opportunities for children to have relationships with friends in an environment that is rich in language, (Piaget, 1973), be able to exemplify and support children's language development to solve problems, (Bergen, 2002; Rosen, 1974), provide various play materials (Synodi, Linardakis, Sadauskienè, Kochanskienè, \& Rimavičiené, 2019), and develop a number of games that can stimulate a number of children's learning activities. When children play, there are two aspects (physical and psychological) that function. To make the two aspect function, physical activity must first be stimulated. When the sensor and motor (sensory motoric) devices are functioned, 
then that is when the children learn. Their learning includes: learning to look at something from what they see, learning to understand something from what they hear, learning to feel something from what they hold, learning something from what they endanger, learning something that is stamped through their tongue. Therefore, stimulation is needed through a number of interesting, challenging, and safe game tools, so that learning processes occur that are in line with the developmental needs of their age (Synodi et al., 2019).

The 2013 curriculum for early childhood education in Indonesia responds to this challenge by building a curriculum that encourages learning based on a scientific approach. Developing a number of activities that can stimulate the growth and development of the early childhood can be carried out through a scientific approach that emphasizes activity-based learning, observation, questioning, prediction, carrying out experiments, and integrating a number of abilities by communicating them (Gerde, Pierce, Lee, \& Van Egeren, 2018). When looking at these activities, the learning approach used as the reference for the early childhood education curriculum is learning by using a playground which is very possible to encourage all these activities. At the beginning of the learning, teachers need to provide opportunities for children to be involved in observations. This activity begins when the teachers present a number of the game tools as an effort to stimulate the child to do hands-on experiences. This activity is the beginning to provoke the emergence of various questions from the children, the association of old experiences with new experiences, the encouragement to conduct various experiments, and finally doing so enables children to have materials to report as a result of both individual and group activities (Gerde, Schachter, \& Wasik, 2013).

However, the reality is that learning in early childhood education is dominated by two extreme learning models, namely very academic learning and full play learning. Very academic learning is carried out with drilling methods oriented to the ability to read, write and count. While, full play learning is carried out by only nurturing. both models are based on neither philosophical nor psychological foundations that are appropriate to the needs of the early childhood development. On the other hand, entering the $21 \mathrm{st}$ century, the world of education is faced with an era of human quality competition that begins with the renewal of learning because the real change of the world begins with a class change(Darling-Hammond, 2016).

This research is based on the problem of the low child development in the problem solving abilities. This is indicated by the ability to answer the teachers' questions that are convergent, lazy to ask questions, and tend to answer the teachers' questions by relying on the answers of the children's friends. The purpose of this study was to determine the effect of scientific approach-based learning on problem solving abilities in early childhood. This research was based on the assumptions about the characteristics of the early childhood and the advantages of a scientific approach that could be developed in a number of models of learning based on playing in the early childhood education. The hypothesis proposed in this study was that there was a learning-based influence on the ability to solve problems for the early childhood. 
Our research is led by three research questions, which are: How do activities occur in the scientific approach? Is there an influence between the scientific approach with the ability to solve early childhood problems? How does the scientific approach affect problem-solving in early childhood?

\section{The Aim of the Study}

The purpose of this study is to assess the problem solving skills of kindergarten children (aged 5-6 years) and to examine the effect of scientific approach based learning process on problem solving skills in early childhood.

\section{METHOD}

\section{Population and sampling}

The population and sample in this study were 32 children of B class al-kautsar bandar lampung kindergarten. The sampling technique used a purposive random sampling, where the entire population is a member of sample. The research subjects were 32 children with an age range of 5-6 years in Al Kautsar Kindergarten Bandar Lampung. The Al-Kautsar Kindergarten was chosen as a place of the research based on two criteria: (1) this kindergarten has students from various socioeconomic statuses and diverse regional cultures, and (2) it has been accredited by the government. So, the sample is relatively representative to be studied. Researchers have received permission from the child's parents.

\section{Data collection tools}

The data collection tools used are observation, documentation guidelines, and performance assessment. The data were analysed descriptively and using simple linear regression. Observations are used to assess the performance of children with a rating scale. Rating with rating scale form begins with the making of a rubric grid guide to the assessment of learning activities based on scientific approaches and problem-solving ability. And there are additional tests, performance tasks to see the results of the ability to solve problem.

Problem-solving efforts consist of several structured components of "Knowledge - skills -understanding" that can be measured are characterized by: 1) The child shows explorative abilities such as identify the parts of the object being observed 2) The child demonstrates the ability of the investigator to be marked with the child comparing observed objects with other objects. 3) The child can look for causes of problems such as connecting the structure that an object has that is observed by the function of the object 4) Can apply knowledge or experience in context the new one is marked by the child restates a concept which he got 5) Children build alternative solutions by finding away get out of a difficulty to achieve a goal and, 6) The child communicates solutions by presenting concepts in various forms of mathematical representation.

The reliability testing of the instrument problem solving used in this study was internal consistency. This test is done by trying the instrument just once. Reliability using the 
Spearman brown formula obtained a reliability coefficient of 0.46 with the category medium (Arikunto, 2013).

Data collection techniques used in addition to observation and documentation guidance is to use tests. Test for problem-solving abilities by using performance assessment. Performance assessment is an assessment with a variety of tasks and situations where test takers are asked to demonstrate an understanding and application of in-depth knowledge, as well as skills in a variety of contexts with desired criteria (Majid, 2009). This assessment is based on observers' observations of student activities as they occur. This assessment is usually used to assess students' ability to make speeches, poetry readings, discussions, problem-solving, student participation in discussions, dancing, playing musical instruments, sports activities, using laboratory equipment, and operating an instrument.

Performance assessment is used to see the ability of problem-solving in children. In this assessment the child is given the task of activities such as sorting the process of the occurrence of butterflies (eggs, caterpillars, cocoons, butterflies) arranging butterfly puzzles, connecting body structures, matching butterfly body parts, arranging letters to form words, counting the number of ants obtained, completing the ant house maze, erupting mountain experiments, demonstrating solutions that children have. This assessment is based on the results of the answers given by children with rating scale.

\section{Scientific approach program}

The concept of Scientific Approach in a way directly involving children in activities, i.e. conducting, Experience information search by asking, finding out the answers to understanding the world with ideas awesome. Learning activities through 5 stages, namely activities:

1) Activities to formulate problems, namely creating atmosphere effective learning such as story telling, dialogue, singing, or asking. Then involve the child directly in all activity by observing objects with all the senses (sight, hearing, contemplation, touch and taster).

2) Activities to form a hypothesis. Begins by asking (Questioning) about something that senses as.

3) the process of confirming or matching of knowledge that is he already has with new knowledge that gives rise to alleged allegations relating to temporary solutions.

4) Activity to collect data. That way of trying (Experimenting) conducting experiments as a step proof of cause and effect.

5) Activity analyzing problems. With the associating stage (Associating), namely connecting knowledge already held about objects observed with new knowledge obtained from the surrounding environment. 
6) Activity concludes. By communicating (Communication), namely the process of strengthening the gaining knowledge new knowledge obtained by children orally and results creation.

\section{Procedure and data collection}

The method used in this study is a quasi-experiment with the design model of the group pretest-posttest design, an experiment carried out in one group without comparison groups by giving pretest and posttest. Quasi-experimental placement of research subjects into the experimental and control groups was carried out non-randomly (Cook \& Campbell, 1979; Shadish, W., Cook, T., and Campbell, 2002). This experiment did not place the subject either in the experimental group or the control group at random. The design used is shown in Tabel 1.

Tabel 1

Research design

\begin{tabular}{lll}
\hline Initial Ability & Treatment & Final Ability \\
\hline Q1 & X & Q2 \\
\hline
\end{tabular}

Source: Data analysis for this article

Q1 = initial ability of the research subjects

$\mathrm{X}=$ treatment

$\mathrm{Q} \quad=$ final ability of the research subjects

The analyzed the data was descriptively and using linear regression techniques. Regression analysis is used to predict how the value of the dependent variable changes if the value of the independent variable is increased or decreased in value (Sugiyono, 2011).

\section{FINDINGS}

From the results of the collection of research data in the field, a descriptive test is then conducted which aims to provide an overview of the spread of data. The data in this study consisted of two independent variables namely the scientific approach and the dependent variable, namely problem-solving.

\section{How do activities occur in the scientific approach?}

The results of the research on activeness before and after being treated are shown in Table 2.

Table 2

Distribution of the activity values (X)

\begin{tabular}{llllll}
\hline & \multicolumn{3}{c}{ Before Being Treated } & \multicolumn{2}{c}{ After Being Treated } \\
Category & Interval & Frequency (f) & Percentage (\%) & Frequency (f) & Percentage (\%) \\
\hline VA & $30-36$ & 0 & 0.00 & 2 & 6.25 \\
A & $23-29$ & 14 & 43.75 & 27 & 84.375 \\
QA & $16-22$ & 18 & 56.25 & 3 & 9.375 \\
LA & $9-15$ & 0 & 0.00 & 0 & 0.00 \\
Total & & 32 & 100.00 & 32 & 100.00 \\
\hline
\end{tabular}


Source: Data analysis for this article

$\begin{array}{ll}\text { VA } & =\text { Very Active } \\ \text { A } & =\text { Active } \\ \text { QA } & =\text { Quite Active } \\ \text { LA } & =\text { Less Active }\end{array}$

Table 2 shows an increase in learning activities when children follow a scientific approach-based learning. This occurs in all categories. To illustrate, this can be seen from the active category (A), which previously covered 14 children $(43.75 \%)$ increased to 27 children (84.375\%). The quite active (QA) category has decreased, initially there were 18 children $(56.25 \%)$ down to 3 children $(9.375 \%)$. This is because there is an increase in activity after learning with a scientific approach so that the category of quite active (QA) increases to active (A). Not only there, the percentage of children with very active (VA) category experienced an increase from none of the children $(0 \%)$ increased to 2 children $(6.25 \%)$.

In general, all children actively respond to problems starting from the preliminary stage, when they are confronted with questions that contain problems, until they explore to answer the questions without being dependent on friends or directed by the teachers. Observing is the beginning of an activity that stimulates all five senses of the children, followed by exploring and finding out about things combined with teachers' guidance to scaffold this process and develop questions about what they see. This method is an effort to help children become good observers (Gerde et al., 2013). After observing activities, then the children are able to understand the object and explain what is being observed. The role of the teachers is to ask questions that guide the children's thinking, and support children to describe and label what they see while supporting children to develop concepts based on their observations (Copple, Bredekamp, \& National Association for the Education of Young Children., 2009; Dickinson \& Porche, 2011).

In order that children are able to build problem-solving skills, teachers create conducive classroom conditions that attract children to ask many questions that demand scientific inquiry. When young children develop skills to recognize and ask questions, asking and responding to questions turns out to be learning activities while supporting language development (Dickinson \& Porche, 2011; Wasik \& Iannone-Campbell, 2012). During the process of generating questions, children do not only learn how to ask factual questions about something they observe, but they also raise critical questions about the world around them. When critical thinking has arisen in the children, then the children are able to gather information to test the expectations they formulated before, until they finally communicate the results they get. The results of research on the ability to solve problems before and after being treated are shown in Table 3. 
Table 3

Value distribution of the problem solving abilities (Y)

\begin{tabular}{llllll}
\hline & & \multicolumn{2}{l}{ Before Being Treated } & \multicolumn{2}{l}{ After Being Treated } \\
\cline { 3 - 6 } Category & Interval & Frequency (f) & Percentage $(\%)$ & Frequency (f) & Percentage $(\%)$ \\
\hline DVW & $20-24$ & 0 & 0.00 & 3 & 9.37 \\
DAE & $15-19$ & 6 & 18.75 & 17 & 53.13 \\
STD & $10-14$ & 26 & 81.25 & 12 & 37.50 \\
UD & $5-9$ & 0 & 0.00 & 0 & 0.00 \\
Total & & 32 & 100.00 & 32 & 100 \\
\hline
\end{tabular}

Source: Data analysis for this article

Information:

DVW = Developed Very Well

DAE $\quad=$ Developed as Expected

STD $\quad=$ Started to Develop

UD $\quad=$ Undeveloped

Table 3 shows an increase in the children's learning activities after being given treatment using the scientific approach. A number of problem solving indicators (including identifying the parts of the object being observed, comparing the objects observed with other objects, connecting the structure of the object that observes the function of the object, restating a concept that the children can, finding a way out of a difficulty, communicating solutions in their own language) increased in all categories, especially from the category of Started to Develop (STD) to Developed as Expected (DAE) by $34.38 \%$ (from $37.5 \%$ to $53.13 \%$ ).

The results suggest significant changes in the problem solving through the scientific approach-based learning. There is an increase in problem solving ability between before and after treatment with the scientific approach. The category STD experienced a decline in the number of children, from 26 children $(81.25 \%)$ dropped to 12 children $(37.50 \%)$. This is due to an increase in problem solving skills after learning with a scientific approach so that the STD increases to DAE. Also, the percentage for children in the DAE category experienced an increase of 6 children $(18.75 \%)$, increasing to 17 children (53.13\%). and in the Developed Very Well (DVW) category, there was an increase that was initially none of the 3 children (9.37) that were Developed Very Well (DVW). It can be concluded, that there is influence in learning that uses a scientific approach to the ability to solve problems in early childhood.

Is there an influence between the scientific approach with the ability to solve early childhood problems? Increasing problem solving by applying scientific approach.

The results of a comparative statistical description of the value of problem solving before treatment and after treatment in the table 4 below. 
Table 4

Comparison of the value problem solving by applying scientific approach

\begin{tabular}{lllll}
\hline Aspect & & & & \\
Problem-Solving & $\mathrm{N}$ & Minimum & Maximum & Mean \\
\hline Before treatment & 32 & 12.00 & 19.00 & 14.0938 \\
After treatment & 32 & 12.00 & 20.00 & 15.0000 \\
\hline
\end{tabular}

From the data it is known that the early childhood problem-solving variable before treatment has the minimum value of 12.00; the maximum value of 19.00; and an average value of 14.0938 from 32 children. An after treatment early childhood problem-solving, has the minimum value of 12.00; the maximum value of 20.00, and average value of 15.00 from 32 children. Based on the data, the ability of problem-solving by applying the scientific approach has increased, this can be seen from the average before treatment value of 14.0938, an increase in the average after treatment value of 15 .

\section{How does the scientific approach affect problem solving in early childhood?}

The normality test uses the Kolmorgorov Smirnov test with a significance value of 0.07 ( $p>0.05$ ) indicating that the data is normally distributed. Linearity test seen from the value of deviation from linearity with a significance level of $1.053(\mathrm{p}>0.05)$ indicates a linear relationship. The results of multicollinearity test revealed the value of VIF 1.000 (VIF <10) and tolerance value 1.000 (tolerance> 0.1) showed there is no multicollinearity. The heteroscedasticity test with a p value of 0.793 ( $p>0.05$ ) has fulfilled the prerequisites for regression analysis. The following are the results of the regression analysis:

Table 5

Regression analyzed

\begin{tabular}{llllll}
\hline \multirow{2}{*}{ Model } & \multicolumn{2}{l}{ Unstandardized Coefficients } & $\begin{array}{l}\text { Standardized } \\
\text { Coefficients }\end{array}$ & & \\
\cline { 2 - 4 } & $\mathrm{B}$ & Std. Error & Beta & & Sig \\
\hline (Constant) & -1.637 & 2.498 & & -.655 & .517 \\
Saintific approach & .697 & .103 & .778 & 6.785 & .000 \\
\hline
\end{tabular}

The result of regression analysis obtained to predict $\mathrm{X}$ if the independent variable is set $\mathrm{Y}=1.637+0.697 \mathrm{X}$, with a regression coefficient $\mathrm{b}$ of 0.697 identifying the average value of problem solving ability using scientific approach-based learning. Based on this equation, if the value of $\mathrm{X}$ is known, then the value of $\mathrm{Y}$ can be known by multiplying the value of $X$ with a coefficient $(0.697)$ which is then summed with a constant value (1.637). This means that the value of $\mathrm{X}$ increases, then the value of $\mathrm{Y}$ increases, according to the direction of the regression coefficient, the regression coefficient is positive. So, the increasing value of the scientific approach $(\mathrm{X})$ also increases the value of the problem solving ability (Y) of early childhood. Thus, it can be concluded that there is an effect of learning based on a scientific approach on the problem-solving ability of children aged 5-6 years at the Al-Kautsar Kindergarten Bandar Lampung. 


\section{DISCUSSION}

The scientific approach has proven to be a reference to learning models that are fun for early childhood, because this approach can encourage learning models combined with play. The learning like this does not separate children from their world (Edwards \& Cutter-Mackenzie, 2013). According to the Vygotsky's perspective, the play is a manifestation of the experience (Gupta, 2009; Vygotsky, 1967). The experience can build activities in various contexts, and in turn, this results in an understanding of a concept and shapes behaviour based on the experiences learned directly (Kolb, 2014). It is also suggested that play provides children with opportunities to interact with materials around them that assist in constructing their knowledge of the world (Piaget, 1962).

The learning models based on scientific approaches encourage early childhood to submit and answer questions using a series of unstructured activities, but challenge children to create comprehensive and meaningful experiences. Preschool children provide senses in accessing information and recognizing environment as human being. the information obtained by children through their senses of observing the events, building the causaleffect relationship between the concepts and cases they observed, playing research instincts, performing measurements, that is, by using scientific processes (Unal, \&Akman, 2006). Developing a number of activities that can stimulate the growth and development of the early childhood through a scientific approach that emphasizes activity-based learning, observation, questioning, prediction, carrying out experiments, and integrating a number of abilities by communicating them (Gerde et al., 2013).

The scientific approach process is a series of finding out by exploring through five stages: observing, questioning, collecting information, associating, communicating. Observing refers to an activity of using all the senses (sight, hearing, smell, touch, and taste) to recognize an object that is being observed. Questioning, or asking a question, is a process of thinking that is driven by the child's curiosity about an object or event. Collecting information is a process of finding answers to the questions the child presents at the questioning stage. Associating is a reasoning process for early childhood to connect or match the knowledge that it already has with the new experiences it has gained. Communicating is a process of strengthening new knowledge/skills acquired by children. Communicating can be done in such various ways as spoken language, movement, and work. It is important to help children understand the world, collect and process information as a key basis of children learning scientific thinking. Developing scientific thinking from an early age will produce children who think creatively and critically.

Researchers recommend that scientific learning be introduced before children enter schools, even children from birth (Eshach \& Fried, 2005; Watters, Diezmann, Grieshaber, \& Davis, 2001). Involving children in the scientific investigations uses all activities that support children to build conceptually related knowledge because at each step the children use various skills to find new information about concepts or solve problems (Gelman \& Brenneman, 2004, 2012). The development of problem solving and making decision skills in children is influenced by the activity types performed and 
the activity materials used( Lambert, 2001). Also, early childhood educators are often recommended to use play(Fisher, Hirsh-Pasek, Golinkoff, Singer, \& Berk, 2012) in their classrooms to promote young children's learning and interest in mathematics, literacy, and problem solving (Hirsh-Pasek, Michnick Golinkoff, Berk, \& Singer, 2010).

The development of problem solving skills in children is directly associated with readiness, the child's age, attitude or respond towards the problem, as well as capacities, attitude, family, information, experiences, environment, and compentence (Hirsh-Pasek et al., 2010). In addition, the children who receive problem solving experiences and encouraging them with education problems are important for them to understand the problem solving skills (Tan \& Temiz, 2003). The development of critical thinking and problem solving skills are directly related to the acquisition of science process skills. Real science incorporates many things to which young children are most particularly open: creative thinking and problem solving, experimentation, and invention (Chaillé \& Britain, 2003).

The learning models based on scientific approaches have proven to have an impact on improving all aspects of the early childhood development in a comprehensive manner. (Tang, Coffey, Elby, \& Levin, 2009) says that scientific approach has the characteristics of "doing science". This is perhaps due to the findings that children who engage in scientific exploration in early childhood have a better understanding of science concepts later in life (Eshach \& Fried, 2005). The development of the scientific thinking process skills in children also encourage the development of abilities in the solution of the problems in their life. It is imperative to obtain the scientific thinking process skills and support the children in this subject starting from the early period during the acquisition of the problem solving skill, this is significant in terms of the development of the child. Cooperative problem solving with peers plays an important role in promoting children's social and cognitive development(Ramani \& Brownell, 2014). This is what has become an effort to prepare them to be able to adapt to the future, create the future and thus change their own future especially as a good citizens in the future. The ability to solve problems creatively, independently, and cooperatively is part of democratic life skills.

\section{CONCLUSION}

This study examines the influence of the scientific approach-based learning process to problem-solving skills of early childhood and the difference between before and after applying the scientific approach-based learning process. Our findings reveal that the scientific approach-based learning is not only able to increase physical activity but also the mentality which leads to the problem solving abilities. This happens because it is supported by the learning conditions that are not separated from the atmosphere of play, the teacher functions him/herself not as a teacher but as a potential coach of the children. When playing, children become very active in functioning all the sensors (the five senses) and the motor through moving, asking, exploring, trying, remembering their experiences, proving and reporting about something. At this time, they are studying seriously. The learning is a complex action and behaviour of children or students involving physical and psychological aspects by functioning all senses simultaneously (Bidzan-Bluma \& Lipowska, 2018; Donnelly et al., 2016). 
Implications for teachers, teachers can use to provide broad opportunities for children to play through learning based on a scientific approach with models that are applicable so that learning is fun and provides meaningful experiences that will invite children directly to real experiences that will improve their problem-solving abilities. the increase in scientific approaches also increases the ability to solve child problems. The scientific approach can provide an understanding of children in recognizing, understanding, obtaining, and processing information from various sources through the stages of observing, asking, trying, reasoning, and forming communication networks. This result can be used as a reference in improving children's problem-solving abilities.

The population in this study was limited to one school only, so the research subjects were 32 children. This research has already been carried out, but the subject of research in particular regarding the influence of the scientific approach to problem solving skills in early childhood in Bandar Lampung has not been done much. Although the subject is used little, the results of this study can be a reference for teachers in improving the ability to solve problems in early childhood.

The results of this study can be used as an appropriate reference and in the development of the ability to solve early childhood problems especially in predicting how much influence the scientific approach to problem-solving skills in early childhood. To develop problem-solving skills in early childhood learning can be done with a scientific approach. Therefore, this study can be used as a reference for teachers in improving problem solving skills in early childhood using the scientific approach.

To improve the ability to problem solving can use scientific approach. The scientific approach provides pleasant and meaningful experiences that will invite children directly to real experiences that will improve their problem solving abilities. Implication for further research, this study has limitations on the method used that is the number of samples that are not much, in the future can be expanded again by adding more samples. Not only carried out in kindergarten but can also be followed up to a further level of primary school research.

\section{ACKNOWLEDGMENTS}

The authors would like to express their gratitude and appreciation to Universitas Lampung for its financial support with contract number (0721 701609) and also the principals, teachers and children of Al-Kautsar Kindergarten for their participation in this study.

\section{REFERENCES}

Aisyah, S., Amini, M., Chandrawati, T., \& Novita, D. (2014). Perkembangan dan konsep dasar pengembangan anak usia dini. (Child Development). Jakarta: Terbuka University.

Arikunto, S. (2013). Prosedur Penelitian: Suatu Pendekatan Praktik. Jakarta: Rineka Cipta. 
Bergen, D. (2002). The role of pretend play in children's cognitive development. Early Childhood Research \& Practice, 4(1), n1.

Bergen, D. (2002). E C1NP Development.

Bidzan-Bluma, I., \& Lipowska, M. (2018). Physical activity and cognitive functioning of children: A systematic review. International Journal of Environmental Research and Public Health. https://doi.org/10.3390/ijerph15040800

Chaillé, C., \& Britain, L. (2003). The Young Child as Scientist: A Constructivist Approach to Early Childhood Science Education. In Third Edition.

Cook, T. D., \& Campbell, D. T. (1979). Quasi-experimentation: Design \& analysis issues in field settings. In Houghton Mifflin.

Copple, C., Bredekamp, S., \& National Association for the Education of Young Children. (2009). Developmentally appropriate practice in early childhood programs serving children from birth through age 8. National Association for the Education of Young Children.

Darling-Hammond, L. (2016). Research on Teaching and Teacher Education and Its Influences on Policy and Practice. Educational Researcher. https://doi.org/10.3102/0013189X16639597

Dickinson, D. K., \& Porche, M. V. (2011). Relation Between Language Experiences in Preschool Classrooms and Children's Kindergarten and Fourth-Grade Language and Reading Abilities. Child Development, 82(3), 870-886. https://doi.org/10.1111/j.14678624.2011.01576.x

Donnelly, J. E., Hillman, C. H., Castelli, D., Etnier, J. L., Lee, S., Tomporowski, P., ... Szabo-Reed, A. N. (2016). Physical activity, fitness, cognitive function, and academic achievement in children: A systematic review. Medicine and Science in Sports and Exercise. https://doi.org/10.1249/MSS.0000000000000901

Edwards, S., \& Cutter-Mackenzie, A. (2013). Pedagogical Play Types: What Do They Suggest for Learning About Sustainability in Early Childhood Education? International Journal of Early Childhood, 45(3), 327-346. https://doi.org/10.1007/s13158-013-00825

Eshach, H., \& Fried, M. N. (2005). Should science be taught in early childhood? Journal of Science Education and Technology, 14(3), 315-336. https://doi.org/10.1007/s10956-005-7198-9

Fisher, K., Hirsh-Pasek, K., Golinkoff, R. M., Singer, D. G., \& Berk, L. (2012). Playing Around in School: Implications for Learning and Educational Policy. In The Oxford Handbook of the Development of Play. https://doi.org/10.1093/oxfordhb/9780195393002.013.0025

Gelman, R., \& Brenneman, K. (2004). Science learning pathways for young children. Early Childhood Research Quarterly. https://doi.org/10.1016/j.ecresq.2004.01.009 
Gelman, R., \& Brenneman, K. (2012). Moving young "scientists-in-waiting" onto science learning pathways: Focus on observation. In The journey from child to scientist: Integrating cognitive development and the education sciences. https://doi.org/10.1037/13617-008

Gerde, H. K., Pierce, S. J., Lee, K., \& Van Egeren, L. A. (2018). Early Childhood Educators' Self-Efficacy in Science, Math, and Literacy Instruction and Science Practice in the Classroom. Early Education and Development, 29(1), 70-90. https://doi.org/10.1080/10409289.2017.1360127

Gerde, H. K., Schachter, R. E., \& Wasik, B. A. (2013). Childhood Curriculum. (September). https://doi.org/10.1007/s10643-013-0579-4

Gupta, A. (2009). Vygotskian perspectives on using dramatic play to enhance children's development and balance creativity with structure in the early childhood classroom. Early Child Development and Care, 179(8), 1041-1054. https://doi.org/10.1080/03004430701731654

Haenilah, E. Y. (2015). Kurikulum dan pembelajaran PAUD. Yogyakarta: Media Akademi.

Kolb, D. A. (2014). Experiential learning: Experience as the source of learning and development: FT press.

Hart, J. L., \& Tannock, M. T. (2013). Playful Aggression in Early Childhood Settings. 38(3), 106-114. https://doi.org/10.1017/cha.2013.14

Hirsh-Pasek, K., Michnick Golinkoff, R., Berk, L. E., \& Singer, D. (2010). A Mandate for Playful Learning in Preschool: Presenting the Evidence. In A Mandate for Playful Learning in Preschool: Presenting the Evidence. https://doi.org/10.1093/acprof:oso/9780195382716.001.0001

Kolb, D. A. (1984). Experiential Learning: Experience as The Source of Learning and Development. Prentice Hall, Inc. https://doi.org/10.1016/B978-0-7506-7223-8.50017-4

Lambert, E. B. (2001). Metacognitive Problem Solving in Preschoolers. Australasian $\begin{array}{llll}\text { Journal of Early } & \text { Childhood, 24-29. }\end{array}$ https://doi.org/10.1177/183693910102600306

Majid, A. (2009). Perencanaan Pembelajaran. Bandung: PT Remaja Rosda Karya

Pellegrini, A. D., \& Smith, P. K. (1998). Physical activity play: The nature and function of a neglected aspect of play. Child Development. https://doi.org/10.1111/j.14678624.1998.tb06226.x

Piaget, J. (1973). The child and reality: Problems of genetic psychology. (Trans. Arnold Rosin). In The child and reality: Problems of genetic psychology. (Trans. Arnold Rosin).

Piaget, J. (2013). The construction of reality in the child. In The Construction of Reality in the Child. https://doi.org/10.4324/9781315009650 
Ramani, G. B., \& Brownell, C. A. (2014). Preschoolers' cooperative problem solving: Integrating play and problem solving. Journal of Early Childhood Research. https://doi.org/10.1177/1476718X13498337

Rosen, C. E. (1974). The Effects of Sociodramatic Play on Problem-solving Behavior among Culturally Disadvantaged Preschool Children. Child Development. https://doi.org/10.1111/j.1467-8624.1974.tb00687.x

Shadish, W., Cook, T., and Campbell, D. (2002). Statistical conclusions: Validity and internal validity. In Experimental and Quasi Experimental Designs for Generilized Causal Inference.

Synodi, E., Linardakis, M., Sadauskienė, R., Kochanskienė, A., \& Rimavičienė, D. (2019). Teachers' Approach to Playfulness in the Process of Education/Learning in Lithuania and Greece. Journal of Pedagogy and Psychology "Signum Temporis." https://doi.org/10.1515/sigtem-2016-0002

Tan, M., \& Temiz, B. (2003). Fen öğretiminde bilimsel süreç becerilerinin yeri ve önemi. Pamukkale Üniversitesi Eğitim Fakültesi Dergisi.

Tang, X., Coffey, J. E., Elby, A., \& Levin, D. M. (2009). The scientific method and scientific inquiry: Tensions in teaching and learning. Science Education, n/a-n/a. https://doi.org/10.1002/sce.20366

Trianto. (2014). Model Pembelajaran Terpadu. Konsep Strategi Dan Implementasinya Dalam KTSP.

Turk, D. J., Gillespie-Smith, K., Krigolson, O. E., Havard, C., Conway, M. a., \& Cunningham, S. J. (2015). Selfish learning: The impact of self-referential encoding on children's literacy attainment. Learning and Instruction, 40, 54-60. https://doi.org/10.1016/j.learninstruc.2015.08.001

Ünal, M., \& Akman, B. (2006). OKUL ÖNCESI ÖĞRETMENLERININ FEN EĞITIMINNE KARŞI GÖSTERDIKLERİ TUTUMLAR. Hacettepe Üniversitesi Eğitim Fakültesi Dergisi, 30(30), 251-257

Urbani, J. M., Roshandel, S., \& Michaels, R. (2017). Developing and Modeling 21stCentury Skills with Preservice Teachers.

Vygotsky, L. S. (1967). Play and Its Role in the Mental Development of the Child. Soviet Psychology. https://doi.org/10.2753/rpo1061-040505036

Wasik, B. A., \& Iannone-Campbell, C. (2012). Developing vocabulary through purposeful, strategic conversations. Reading Teacher. https://doi.org/10.1002/TRTR.01095

Watters, J. J., Diezmann, C. M., Grieshaber, S. J., \& Davis, J. M. (2001). Enhancing Science Education for Young Children: A Contemporary Initiative. Australasian Journal of Early Childhood. https://doi.org/10.1177/183693910102600202 